Production indicators and health status of calves fed different amounts of rumen undegradable starch and protein

Proizvodni pokazatelji i zdravstveno stanje teladi hranjene različitim udjelima u buragu nerazgradivog škroba i bjelančevina

Koturić, T., Domaćinović, M., Šperanda, M., Mijić, P., Đidara, M., Kolak, B., Klarić, I.

Poljoprivreda/Agriculture

ISSN: $1848-8080$ (Online)

ISSN: 1330-7142 (Print)

http://dx.doi.org/10.18047/poljo.23.2.9

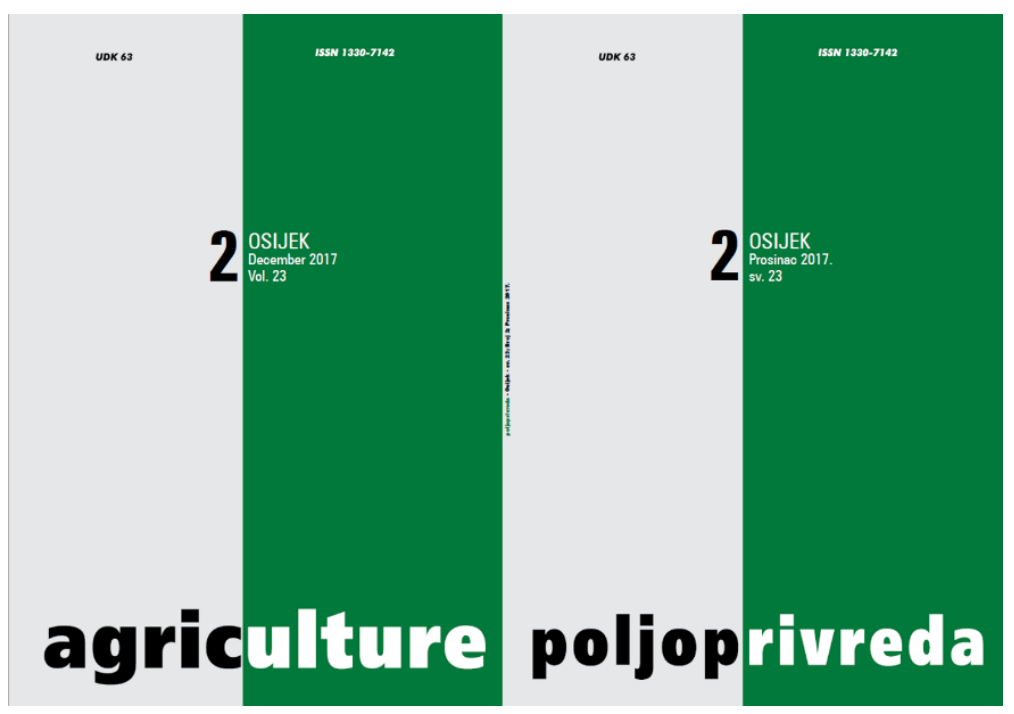

Poljoprivredni fakultet u Osijeku, Poljoprivredni institut Osijek

Faculty of Agriculture in Osijek, Agricultural Institute Osijek 


\title{
PRODUCTION INDICATORS AND HEALTH STATUS OF CALVES FED DIFFERENT AMOUNTS OF RUMEN UNDEGRADABLE STARCH AND PROTEIN
}

\author{
Koturić, $T^{(1)}$, Domaćinović, M. ${ }^{(2)}$, Šperanda, M. ${ }^{(2)}, M i j i c ́, P^{(2)}$, Đidara, M. ${ }^{(2)}, K o l a k, B .^{(3)}, K l a r i c ́, I^{(2)}$ \\ Original scientific paper \\ Izvorni znanstveni članak
}

\section{SUMMARY}

The aim of this study was to determine whether increase in proportion of the rumen undegradable starch (RUS) and rumen undegradable protein (RUP) affects the production performance and health status of calves. The experiment was done on 36 Holstein, seven-day-old calves, divided into three groups of 12 calves, with equal sex ratio. The experiment was conducted in two periods. In the first period, calves were fed with full pasteurized milk and milk replacer and additionally fed with starter mixture with different proportions of rumen undegradable protein and starch: Group I 36.6\% RUP and 16.5\% RUS, Group II 49.1\% RUP and 27.6\% RUS and Group III 53.5\% RUP and 36.5\% RUS. In the second period, calves were fed with milk replacer and grower mixture with different proportions of rumen undegradable protein and starch: Group I 33.5\% RUP and 15.8\% RUS, Group II 48\% RUP and 26.3\% RUS and Group III 54.3\% RUP and 34.6\% RUS. In the first period, calves from the Group III had significantly $(P<0.01)$ higher body weight compared to calves in Group I and II (74.75; 59.36; 66.58 kg), as well as daily weight gain $(0.76,0.49$, $0.61 \mathrm{~kg} / \mathrm{d})$. At the end of the experiment, there was no significant difference in body weight and daily weight gain. The calves in Group I and III had significantly $(P<0.05)$ higher consumption of starter mixture compared to the calves in Group II $(7.48 ; 7.11 ; 4.33 \mathrm{~kg} / \mathrm{d})$, and a significantly $(P<0.05)$ higher overall feed consumption compared to the calves in Group II. The calves in Group II and III had significantly $(P<0.05)$ better feed conversion ratio than the calves in Group I (1.37; 1.50; $2.08 \mathrm{~kg} / \mathrm{kg}$ ). The results of health monitoring (diarrhea, pneumonia) indicate a different proportion of rumen undegradable starch and protein ratio did not have significant effect on calves' health.

Key-words: calves, nutrition, rumen, undegradable starch, undegradable proteins

\section{INTRODUCTION}

During the first months of the extrauterine period under the influence of introducing solid feed in the diets, digestive system undergoes significant anatomical and physiological changes and calves are becoming functional ruminants. In that period, the quality of the nutrients and the nutrient ratio in calves' diet directly create a predisposition for a high growth rate followed by the proper development of organ systems, and overall vitality, which is particularly important for the female calves intended for reproduction (Domaćinović et al., 2009). During the transition period from nonfunctional to functional ruminant, the calves should be fed the diet that stimulates the microbial protein synthesis while simultaneously providing the available undegradable proteins that will optimize the amino acid profile of digested nutrients in the small intestine (Vazquez-Anon et al., 1993). While different dietary sources have different crude protein content (Kočar et al., 2017), there are limited available data regarding the inclusion

(1) Ph.D. Tomislav Koturić - Advisory Service of Osijek-Baranja County, Vinkovačka cesta 63 c, 31000 Osijek, Croatia, (2) Prof. Dr. Matija Domaćinović (matija.domacinovic@pfos.hr),Prof.Dr. Marcela Šperanda, Prof. Dr. Pero Mijić, Assist. Prof. Mislav Đidara, Ph.D. Ivana Klarić - Josip Juraj Strossmayer University of Osijek, Faculty of Agriculture in Osijek, V. Preloga, 1, 31000 Osijek, Croatia, (3) Branko Kolak, Grube d.o.o., Potnjani bb 
of RUP sources in starter mixtures for calves before weaning (Swartz et al., 1991; Abdelgadir et al., 1996; Holtshausen and Cruywagen, 2000; Kazemi-Bonchenar et al., 2015). In addition, NRC (2001) standards do not give RUP recommendations for calves in the preweaning period. This is due to the difficulties in determination of the requirements for degradable and undegradable proteins in rumen of calves at the transition period from non-ruminants to ruminants during the first three months of life (Akayezu et al., 1994). According to Kazemi-Bonchenar et al. (2015), feeding calves in the preweaning period with quality sources of (RUP) can increase the passage of nitrogen and amino acids to the small intestine, which as a result has an increased growth intensity of calves. Since the development of rumen depends on the type of feed and structure of the nutrients, the aim of this study was to determine if an increase in proportion of the rumen undegradable starch (RUS) and RUP affects the growth performance and health status of suckling calves.

\section{MATERIAL AND METHODS}

The research was carried out on a dairy farm Grube d.0.0 in Potnjani in eastern Croatia. A total of 36 Holstein breed calves, 7 days old, were divided into three groups with 12 calves in each group, with the same sex ratio. The experiment was conducted in two periods: 1) Starter period and 2) Grower period. In the first experimental period, calves were fed with full pasteurized milk and milk replacer and additionally with a starter mixture with different proportions of rumen undegradable protein and starch: Group I 36.6\% RUP and $16.5 \%$ RUS, Group II $49.1 \%$ RUP and $27.6 \%$ RUS and Group III 53.5\% RUP and 36.5\% RUS. In the second experimental period, calves were fed with milk replacer and grower mixture with different proportions of rumen undegradable protein and starch: Group I $33.5 \%$ RUP and $15.8 \%$ RUS, Group II $48 \%$ RUP and 26.3\% RUS and Group III 54.3\% RUP and $34.6 \%$ RUS. The first and second experimental period lasted 39 and 22 days, respectively (Table 1).

Table 1. Nutrient and energy value of starter and grower mixture for calves

Tablica 1. Hranjiva i energetska vrijednost starter i grover smjese za telad

\begin{tabular}{|l|c|c|c|c|c|c|}
\hline \multirow{2}{*}{$\begin{array}{l}\text { Nutrient matter } \\
\text { Hranjiva tvar }\end{array}$} & \multicolumn{3}{|c|}{$\begin{array}{c}\text { Starter mixture } \\
\text { Starter smjesa }\end{array}$} & \multicolumn{3}{c|}{$\begin{array}{c}\text { Grower mixture } \\
\text { Grover smjesa }\end{array}$} \\
\cline { 2 - 7 } & $\begin{array}{c}\text { Group I } \\
\text { Skupina I }\end{array}$ & $\begin{array}{c}\text { Group II } \\
\text { Skupina II }\end{array}$ & $\begin{array}{c}\text { Group III } \\
\text { Skupina III }\end{array}$ & $\begin{array}{c}\text { Group I } \\
\text { Skupina I }\end{array}$ & $\begin{array}{c}\text { Group II } \\
\text { Skupina II }\end{array}$ & $\begin{array}{c}\text { Group III } \\
\text { Skupina III }\end{array}$ \\
\hline $\begin{array}{l}\text { Crude protein, g/kg } \\
\text { Sirove bjelančevine, g }\end{array}$ & 180.00 & 181.59 & 180.01 & 160.10 & 160.03 & 160.45 \\
\hline $\mathrm{NE}, \mathrm{MJ} / \mathrm{kg}$ & 6.78 & 6.77 & 6.79 & 6.78 & 6.83 & 6.93 \\
\hline Ca, g/kg & 8.07 & 8.02 & 8.01 & 7.46 & 7.46 & 7.63 \\
\hline P, g/kg & 6.46 & 6.36 & 5.90 & 5.85 & 5.96 & 5.95 \\
\hline $\begin{array}{l}\text { Starch, g/kg } \\
\text { Škrob, g/kg }\end{array}$ & 351.60 & 369.54 & 344.84 & 381.40 & 385.14 & 390.30 \\
\hline $\begin{array}{l}\text { Crude fiber, g/kg } \\
\text { Vlakna, g/kg }\end{array}$ & 56.71 & 65.68 & 67.12 & 55.35 & 66.48 & 65.01 \\
\hline $\begin{array}{l}\text { Ether extract, g/kg } \\
\text { NET, g/kg }\end{array}$ & 569.16 & 558.15 & 540.53 & 594.67 & 582.01 & 575.23 \\
\hline RUS, \% & 16.5 & 27.6 & 36.5 & 15.8 & 26.3 & 34.6 \\
\hline RUP, \% & 36.6 & 49.1 & 53.5 & 33.5 & 48.0 & 54.3 \\
\hline
\end{tabular}

RUS - rumen undegradable starch; RUP - rumen undegradable protein

Calves were fed with liquid food twice a day. Concentrates and water were offered ad libitum during the whole experiment. In the research, production indicators (body weight, daily intake, food consumption and food conversion) and calves' health status were monitored. The body weight of calves was measured on individual bases at the beginning of the experiment and at the end of the first experimental period, as well as at the end of the second experimental period.

Body weight values were used to calculate daily weight gain. The average daily feed consumption (starter and grower mixture) was determined on the basis of individual measurements. Conversion of feed was calculated according to experimental periods and in total. During the experiment, the calves' health status was monitored, and prevalence of diarrhea and pneumonia was determined.
A GLM procedure was used to generate two way ANOVA (STATISTICA version 12; StatSoft Inc., Tulsa, OK, USA). The GLM model included fixed effects of the group and sex to determine any significant differences between production parameters (body weight, daily weight gain, feed intake and feed conversion). In case of significance in variation $(\mathrm{P}<0.05)$, Fisher's post hoc test was performed to determine differences between groups or sexes.

\section{RESULTS AND DISCUSSION}

The effect of an increased proportion of rumen undegradable starch and protein on production parameters of preweaned calves is shown in Tables 2, 3, 4 and 5 . 
Table 2. Body weight $(\mathbf{k g})$ of calves in different experimental groups according to sex

Tablica 2. Prikaz vrijednosti tjelesnih masa teladi po skupinama i spolu tijekom pokusa

\begin{tabular}{|c|c|c|c|c|c|c|c|c|c|c|}
\hline \multirow{2}{*}{\multicolumn{2}{|c|}{$\begin{array}{l}\text { Indicators } \\
\text { Pokazatelji }\end{array}$}} & \multicolumn{2}{|c|}{$\begin{array}{c}\text { Group I } \\
\text { Skupina I }\end{array}$} & \multicolumn{2}{|c|}{$\begin{array}{c}\text { Group II } \\
\text { Skupina II }\end{array}$} & \multicolumn{2}{|c|}{$\begin{array}{c}\text { Group III } \\
\text { Skupina III }\end{array}$} & \multicolumn{2}{|c|}{$\begin{array}{c}\text { P-value } \\
\text { P-vrijednost }\end{array}$} & \multirow{2}{*}{$\begin{array}{l}\text { Interaction } \\
\text { GxS } \\
\text { Interakcija } \\
\text { SxS }\end{array}$} \\
\hline & & $\begin{array}{l}\text { male } \\
\text { muški }\end{array}$ & $\begin{array}{l}\text { female } \\
\text { ženski }\end{array}$ & $\begin{array}{l}\text { male } \\
\text { muški }\end{array}$ & $\begin{array}{l}\text { female } \\
\text { ženski }\end{array}$ & $\begin{array}{l}\text { male } \\
\text { muški }\end{array}$ & $\begin{array}{l}\text { female } \\
\text { ženski }\end{array}$ & $\begin{array}{l}\text { group } \\
\text { skupina }\end{array}$ & sex & \\
\hline $\begin{array}{l}\text { Body weight at the beginning } \\
\text { of the experiment, kg } \\
\text { Tjelesna masa na početku } \\
\text { pokusa, } \mathrm{kg}\end{array}$ & $\begin{array}{l}\bar{x} \\
\text { sd }\end{array}$ & $\begin{array}{r}42.30 \\
3.82\end{array}$ & $\begin{array}{r}39.50 \\
3.48\end{array}$ & $\begin{array}{c}38.92^{b} \\
6.08\end{array}$ & $\begin{array}{l}47.67^{\mathrm{a}} \\
6.57\end{array}$ & $\begin{array}{c}49.71^{\mathrm{a}} \\
1.66\end{array}$ & $\begin{array}{c}40.40^{b} \\
3.53\end{array}$ & 0.106 & 0.469 & 0.001 \\
\hline $\begin{array}{l}\text { Body weight at the transition } \\
\text { from the starter to the grower } \\
\text { mixture, kg } \\
\text { Tjelesna masa na prijelazu sa } \\
\text { starter na grover smjesu, } \mathrm{kg}\end{array}$ & $\begin{array}{l}\bar{x} \\
s d\end{array}$ & $\begin{array}{r}62.40 \\
4.46\end{array}$ & $\begin{array}{r}56.83 \\
6.67\end{array}$ & $\begin{array}{r}63.58 \\
7.58\end{array}$ & $\begin{array}{r}69.58 \\
9.96\end{array}$ & $\begin{array}{r}75.43 \\
7.44\end{array}$ & $\begin{array}{r}73.80 \\
8.87\end{array}$ & 0.0003 & 0.880 & 0.205 \\
\hline $\begin{array}{l}\text { Body weight at the end of the } \\
\text { experiment, kg } \\
\text { Tjelesna masa na kraju poku- } \\
\text { sa, kg }\end{array}$ & $\begin{array}{l}\bar{x} \\
s d\end{array}$ & $\begin{array}{r}78.50 \\
5.87\end{array}$ & $\begin{array}{r}71.08 \\
8.38\end{array}$ & $\begin{array}{r}76.75 \\
7.92\end{array}$ & $\begin{array}{r}86.67 \\
9.91\end{array}$ & $\begin{array}{l}83.36 \\
11.14\end{array}$ & $\begin{array}{l}86.70 \\
13.01\end{array}$ & 0.0526 & 0.558 & 0.116 \\
\hline
\end{tabular}

$a, b, c$ values in same rows with different superscripts are significantly different $(\mathrm{P}<0.05)$

a, b, c vrijednosti u istim retcima s različitim slovima u superskriptu značajno se razlikuju $(P<0,05)$

Average body weight of calves at the beginning of the experiment was uniform, without significant difference between groups (Table 2). At the transition from the starter to the grower mixture (day 39), the highest average body weight was determined in the calves of group III, which was significantly higher $(\mathrm{P}<0.05)$ compared to the body weight of calves in group I and II. Significantly higher body weight of calves was determined in the group II compared to the group I.

The highest average body weight of calves at the end of the experiment was determined in group
III, but the differences were not significant $(P>0.05)$. These results are consistent with Swartz et al. (1991), Holtshausen and Cruywagen (2000), Hill et al. (2007), who also did not determine significant differences in the average body weight of calves fed with different proportions of RUP. The difference in average body weight between the sexes was not significant $(P>0.05)$. Based on significantly higher body weights in third group of calves, it is possible to claim that in the starter period a diet with an increased proportion of the rumen undegradable proteins and starch is more suitable for the sucking calves.

Table 3. Daily weight gain $(\mathrm{kg} / \mathrm{d})$ of calves in different experimental groups according to sex

Tablica 3. Prosječni dnevni prirasti ( $\mathrm{kg} / \mathrm{d}$ ) teladi prikazani po skupinama i spolu

\begin{tabular}{|c|c|c|c|c|c|c|c|c|c|c|}
\hline \multirow{2}{*}{\multicolumn{2}{|c|}{$\begin{array}{l}\text { Period of experiment } \\
\text { Razdoblje pokusa }\end{array}$}} & \multicolumn{2}{|c|}{$\begin{array}{l}\text { Group I } \\
\text { Skupina I }\end{array}$} & \multicolumn{2}{|c|}{$\begin{array}{l}\text { Group II } \\
\text { Skupina II }\end{array}$} & \multicolumn{2}{|c|}{$\begin{array}{l}\text { Group III } \\
\text { Skupina III }\end{array}$} & \multicolumn{2}{|c|}{$\begin{array}{c}\text { P-value } \\
\text { P-vrijednost }\end{array}$} & \multirow{2}{*}{$\begin{array}{c}\text { Interaction } \\
\text { GXS } \\
\text { Interakcija SxS }\end{array}$} \\
\hline & & $\begin{array}{l}\text { male } \\
\text { muški }\end{array}$ & $\begin{array}{l}\text { female } \\
\text { ženski }\end{array}$ & $\begin{array}{l}\text { male } \\
\text { muški }\end{array}$ & $\begin{array}{l}\text { female } \\
\text { ženski }\end{array}$ & $\begin{array}{l}\text { male } \\
\text { muški }\end{array}$ & $\begin{array}{l}\text { female } \\
\text { ženski }\end{array}$ & $\begin{array}{l}\text { group } \\
\text { skupina }\end{array}$ & $\begin{array}{l}\text { sex } \\
\text { spol }\end{array}$ & \\
\hline $\begin{array}{l}\text { 1. Starter period, kg } \\
\text { Starter razdoblje, } \mathrm{kg}\end{array}$ & $\begin{array}{l}\bar{x} \\
s d\end{array}$ & $\begin{array}{l}0.53 \\
0.17\end{array}$ & $\begin{array}{l}0.46 \\
0.12\end{array}$ & $\begin{array}{l}0.65 \\
0.18\end{array}$ & $\begin{array}{l}0.58 \\
0.12\end{array}$ & $\begin{array}{l}0.68 \\
0.21\end{array}$ & $\begin{array}{l}0.88 \\
0.15\end{array}$ & 0.002 & 0.656 & 0.67 \\
\hline $\begin{array}{l}\text { 2. Grower period, } \mathrm{kg} \\
\text { Grover razdoblje, } \mathrm{kg}\end{array}$ & $\begin{array}{l}\bar{X} \\
\text { sd }\end{array}$ & $\begin{array}{l}0.73 \\
0.25\end{array}$ & $\begin{array}{l}0.65 \\
0.16\end{array}$ & $\begin{array}{l}0.60 \\
0.19\end{array}$ & $\begin{array}{l}0.78 \\
0.22\end{array}$ & $\begin{array}{l}0.36 \\
0.33\end{array}$ & $\begin{array}{l}0.59 \\
0.29\end{array}$ & 0.137 & 0.319 & 0.361 \\
\hline
\end{tabular}

\footnotetext{
$a, b, c$ values in same rows with different superscripts are significantly different $(P<0.05)$
}

a, b, c vrijednosti u istim retcima s različitim slovima u superskriptu značajno se razlikuju $(P<0.05)$

Average daily weight gain of calves in the starter period was significantly $(\mathrm{P}<0.05)$ higher in the group III of calves compared to the group I and II (Table 3). The results of daily weight gain of calves in the starter period are consistent with Maige et al. (1994) and Abdelgadir et al. (1996). Average daily weight gain did not significantly $(P>0.05)$ differ among groups in grower period.
The results obtained at the end of the experiment were consistent with Swartz et al. (1991), Abdelgadir et al. (1996), Holtshausen and Cruywagen (2000) and Hill et al. (2007). In the study of Kazemi-Bonchenari et al. (2015), the calves in the control group fed with the starter mixture of $37 \%$ RUP had a higher average daily weight gain compared to the calves fed the starter mix- 
ture with $38.2 \%$ RUP and $40 \%$ RUP. In our experiment there was no significant $(P>0.05)$ difference in average body weight gain between sexes. The highest average body weight gain of the calves in group III during the starter period confirms the starting hypothesis that the suckling calves due to insufficiently developed rumen better use feeds whose proteins and starch are more digestible in the small intestines.

Table 4. Individual average feed intake of calves according to group and sex

Tablica 4. Individualna prosječna potrošnja krmne smjese teladi po skupinama i spolu

\begin{tabular}{|c|c|c|c|c|c|c|c|c|c|c|}
\hline \multirow{2}{*}{\multicolumn{2}{|c|}{$\begin{array}{l}\text { Period of experiment } \\
\text { Razdoblje pokusa }\end{array}$}} & \multicolumn{2}{|c|}{$\begin{array}{l}\text { Group I } \\
\text { Skupina I }\end{array}$} & \multicolumn{2}{|c|}{$\begin{array}{c}\text { Group II } \\
\text { Skupina II }\end{array}$} & \multicolumn{2}{|c|}{$\begin{array}{l}\text { Group III } \\
\text { Skupina III }\end{array}$} & \multicolumn{2}{|c|}{$\begin{array}{c}\text { P-value } \\
\text { P-vrijednost }\end{array}$} & \multirow{2}{*}{$\begin{array}{c}\text { Interaction } \\
\text { GxS } \\
\text { Interakcija SxS }\end{array}$} \\
\hline & & $\begin{array}{l}\text { male } \\
\text { muški }\end{array}$ & $\begin{array}{l}\text { female } \\
\text { ženski }\end{array}$ & $\begin{array}{l}\text { male } \\
\text { muški }\end{array}$ & $\begin{array}{l}\text { female } \\
\text { ženski }\end{array}$ & $\begin{array}{l}\text { male } \\
\text { muški }\end{array}$ & $\begin{array}{l}\text { female } \\
\text { ženski }\end{array}$ & $\begin{array}{l}\text { group } \\
\text { skupina }\end{array}$ & $\begin{array}{l}\text { sex } \\
\text { spol }\end{array}$ & \\
\hline $\begin{array}{l}\text { 1. Starter period, } \mathrm{kg} \\
\text { Starter razdoblje, } \mathrm{kg}\end{array}$ & $\begin{array}{l}\bar{X} \\
\text { sd }\end{array}$ & $\begin{array}{l}7.31 \\
3.32\end{array}$ & $\begin{array}{l}7.61 \\
2.38\end{array}$ & $\begin{array}{l}4.48 \\
1.82\end{array}$ & $\begin{array}{l}4.18 \\
2.12\end{array}$ & $\begin{array}{l}6.70 \\
1.83\end{array}$ & $\begin{array}{l}7.68 \\
1.33\end{array}$ & 0.002 & 0.662 & 0.777 \\
\hline $\begin{array}{l}\text { 2. Grower period, kg } \\
\text { Grover razdoblje, } k g\end{array}$ & $\begin{array}{l}\bar{X} \\
\text { sd }\end{array}$ & $\begin{array}{r}20.58 \\
2.97\end{array}$ & $\begin{array}{r}23.23 \\
5.13\end{array}$ & $\begin{array}{r}17.03 \\
4.60\end{array}$ & $\begin{array}{r}19.22 \\
8.90\end{array}$ & $\begin{array}{r}20.02 \\
6.53\end{array}$ & $\begin{array}{r}26.00 \\
8.72\end{array}$ & 0.178 & 0.114 & 0.746 \\
\hline
\end{tabular}

$a, b, c$ values in same rows with different superscripts are significantly different $(P<0.05)$

$a, b, c$ vrijednosti u istim retcima s različitim slovima u superskriptu značajno se razlikuju $(P<0,05)$

Consumption of the starter mixture by the calves in group I and group III was significantly $(P<0.05)$ higher compared to the calves in group II during the starter period of the experiment (Table 4). During the grower period of the experiment, the calves of the groups I and III achieved higher consumption compared to the group II, but differences were not significant $(\mathrm{P}>0.05)$.

Maiga et al. (1994), in accordance with the results of this study, confirmed higher consumption of feed by the calves fed the starter with a higher proportion in rumen undegradable carbohydrates and proteins while Kazemi-Bonchenari et al. (2015) determined higher con- sumption of feed by the calves fed starter mixture with a lower level of RUP. Swartz et al. (1991), Holtshausen and Cruywagen (2000), and Hill et al. (2007) did not determine differences in the starter mixture consumption when fed different proportion of rumen undegradable protein. In our experiment there was no statistically significant difference $(\mathrm{P}>0.05)$ in the feed consumption between sexes during the experimental period.

The higher consumption of feed determined in the third group of calves suggests that the diet with increased proportion of RUS and RUP has better organoleptic properties and is therefore consumed more by the calves.

Table 5. Feed conversion (concentrate + whole milk/milk replacer) in different experimental groups according to group and sex $(\mathbf{k g} / \mathbf{k g})$

Tablica 5. Konverzija hrane (krmna smjesa i mlijeko/mliječna zamjenica) teladi praćenih po skupinama i spolu, $\mathrm{kg} / \mathrm{kg}$

\begin{tabular}{|c|c|c|c|c|c|c|c|c|c|c|}
\hline \multirow{2}{*}{\multicolumn{2}{|c|}{$\begin{array}{l}\text { Period of experiment } \\
\text { Razdoblje Pokusa }\end{array}$}} & \multicolumn{2}{|c|}{$\begin{array}{l}\text { Group I } \\
\text { Skupina I }\end{array}$} & \multicolumn{2}{|c|}{$\begin{array}{l}\text { Group II } \\
\text { Skupina II }\end{array}$} & \multicolumn{2}{|c|}{$\begin{array}{l}\text { Group III } \\
\text { Skupina III }\end{array}$} & \multicolumn{2}{|c|}{$\begin{array}{c}\text { P-value } \\
\text { P-vrijednost }\end{array}$} & \multirow{2}{*}{$\begin{array}{c}\text { Interaction } \\
\text { GxS } \\
\text { Interakcija SxS }\end{array}$} \\
\hline & & $\begin{array}{l}\text { male } \\
\text { muški }\end{array}$ & $\begin{array}{l}\text { female } \\
\text { ženski }\end{array}$ & $\begin{array}{l}\text { male } \\
\text { muški }\end{array}$ & $\begin{array}{l}\text { female } \\
\text { ženski }\end{array}$ & $\begin{array}{l}\text { male } \\
\text { muški }\end{array}$ & $\begin{array}{l}\text { female } \\
\text { ženski }\end{array}$ & $\begin{array}{l}\text { group } \\
\text { skupina }\end{array}$ & $\begin{array}{l}\text { sex } \\
\text { spol }\end{array}$ & \\
\hline $\begin{array}{l}\text { 1. Starter period, } \mathrm{kg} \\
\text { Starter razdoblje, } \mathrm{kg}\end{array}$ & $\begin{array}{l}\bar{X} \\
\text { sd }\end{array}$ & $\begin{array}{l}1.93 \\
0.51\end{array}$ & $\begin{array}{l}2.22 \\
0.53\end{array}$ & $\begin{array}{l}1.44 \\
0.41\end{array}$ & $\begin{array}{l}1.56 \\
0.29\end{array}$ & $\begin{array}{l}1.57 \\
0.55\end{array}$ & $\begin{array}{l}1.22 \\
0.20\end{array}$ & 0.0014 & 0.924 & 0.138 \\
\hline $\begin{array}{l}\text { 2. Grower period, } \mathrm{kg} \\
\text { Grover razdoblje, } \mathrm{kg}\end{array}$ & $\begin{array}{l}\bar{X} \\
\text { sd }\end{array}$ & $\begin{array}{l}2.39 \\
0.72\end{array}$ & $\begin{array}{l}2.75 \\
0.43\end{array}$ & $\begin{array}{l}2.56 \\
0.50\end{array}$ & $\begin{array}{l}2.17 \\
0.80\end{array}$ & $\begin{array}{l}2.93 \\
0.67\end{array}$ & $\begin{array}{l}2.65 \\
0.32\end{array}$ & 0.379 & 0.658 & 0.325 \\
\hline
\end{tabular}

$a, b, c$ values in same rows with different superscripts are significantly different $(\mathrm{P}<0.05)$

$a, b, c$ vrijednosti u istim retcima s različitim slovima u superskriptu značajno se razlikuju $(P<0,05)$

In the starter period the calves of group II and III achieved a significantly $(\mathrm{P}<0.05)$ better feed conversion compared to the group I (Table 5). Feed conversion between groups in the grower period did not significantly $(P>0.05)$ differ. Kazemi-Bonchenari et al. (2015) determined a better conversion of a starter mixture with a medium and high RUP proportion compared to the low RUP proportion in a starter for calves in prewening period. Swartz et al. (1991), Maiga et al. (1994) and Holtshausen and Cruywagen (2000) did not observe differences in the feed conversion in calves fed starter mixtures with different proportions of rumen undegradable proteins and starch.

Better feed conversion in calves of the group III along with improved consumption of feed explains the higher daily body weight gain and higher body weights of calves that had consumed the diet with the highest proportion of RUP.

Monitoring of calves health status included determination of diarrhea and pneumonia prevalence. The 
prevalence of diarrhea was the lowest in group II, 6 calves $(4 \hat{\circ}: 2$ P), slightly higher in group III, 7 calves

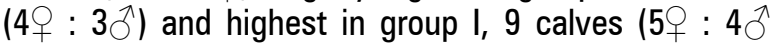
). In all groups, the prevalence of diarrhea was determined in the first 15 days of the experiment, similar to Domaćinović et al. (2009). Pneumonia was determined in group I and group II in 1 calf. From the results obtained in this study it can be concluded that dietary treatments with different proportions of RUP and RUS did not have a significant effect on the health status of the calves.

\section{CONCLUSION}

Based on the results of the basic production indicators in this study, it can be concluded that the right proportion of starch and protein in the diet is very important at the beginning of the forestomach development in calves. Therefore, besides the choice of feeds and its textures, in preparation of calves diet, it is very important to take into account the proportion of rumen undegradable proteins and starch.

\section{REFERENCES}

1. Abdelgadir, I.E.O., Morrill, J.L., Higgins, J.J. (1996): Effect of roasted soybeans and corn on performance and ruminal and blood metabolites of dairy calves. Journal of Dairy Science, 79: 465-474.

doi: http://dx.doi.org/10.3168/jds.S0022-0302(96)76387-7

2. Akayezu, J.M., Linn, J.G., Otterby, D.E., Hansen, W.P., Johnson, D.G. (1994): Evaluation of calf starters containing different amounts of crude protein for growth of Holstein calves. Journal of Dairy Science, 77: 18821889.

doi: http://dx.doi.org/10.3168/jds.S0022-0302(94)77130-7

3. Domaćinović, M., Antunović, Z., Šperanda, M., Mijić, P., Klarić, I., Bagarić, D. (2009): Proizvodni učinak punomasnog mlijeka i mliječne zamjenice $u$ othrani teladi. Mljekarstvo, 59(4): 296-301.

4. Hill, T.M., Aldrich, J.M., PAS, Schlotterbeck, R.L., Bateman, H.G. II (2007): Protein concentrations for star- ters fed to transported neonatal calves. The Professional Animal Scientist, 23: 123-134.

doi: http://dx.doi.org/10.15232/S1080-7446(15)30952-9

5. Holtshausen, L., Cruywagen, C.W. (2000): The effect of dietary rumen degradable protein content on veal calf performance. South African Journal of Animal Science, 30: 204-211.

doi: http://dx.doi.org/10.4314/sajas.v30i3.3853

6. Kazemi-Bonchenari, M., Alizadeh, A.R., Tahriri, A.R., Karkoodi, K., Jalali, S., Sadri, H. (2015): The effects of partial replacement of soybean meal by xylose-treated soybean meal in the starter concentrate on performance, health status, and blood metabolites of holstein calves. Italian Journal of Animal Science, 14: 138-142.

doi: http://dx.doi.org/10.4081/ijas.2015.3680

7. Maiga, H.A., Schingoethe, D.J., Ludens, F.C., Tucker, W.L., Casper, D.P. (1994): Response of calves to diets that varied in amounts of ruminally degradable carbohydrate and protein. Journal of Dairy Science, 77: 278-283.

8. Matoša Kočar, M., Sudarić, A., Vila, S., Petrović, S., Rebekić, A., Josipović, A., Markulj Kulundžić, A. (2017): Variability in phenotypic expression of seed quality traits in soybean germplasm. Agriculture, 23(1): 40-48.

doi: http://dx.doi.org/10.18047/poljo.23.1.7

9. National Research Council. (2001): Nutrient requirements of dairy cattle. $7^{\text {th }}$ revised ed. National Academy Press, Washington, DC., p. 408.

10. Swartz, L.A., Heinrichs, A.J., Varga, G.A., Muller, L.D. (1991): Effects of varying dietary undegradable protein on dry matter intake,growth, and carcass composition of Holstein calves. Journal of Dairy Science, 74: 38843890.

doi: http://dx.doi.org/10.3168/jds.S0022-0302(91)78581-0

11. Vazquez-Anon, M., Heinrichs, A.J., Aldrich, J.M., Varga, G.A. (1993): Effect of postweanlng age on rate of in situ protein disappearance in calves weaned at 5 weeks of age. Journal of Dairy Science, 76(9): 2749-2757.

doi: http://dx.doi.org/10.3168/jds.S0022-0302(93)77612-2 


\section{PROIZVODNI POKAZATELJI I ZDRAVSTVENO STANJE TELADI HRANJENE RAZLIČITIM UDJELIMA U BURAGU NERAZGRADIVOG ŠKROBA I BJELANČEVINA}

\section{SAŽETAK}

Cilj ovog istraživanja bio je utvrditi kako povećan udio u buragu nerazgradivoga škroba (RUS) i bjelančevina (RUP) utječe na proizvodni učinak i zdravstveno stanje teladi. Pokus je proveden na 36 teladi Holstein pasmine, prosječne starosti 7 dana, podijeljene u tri skupine s po 12 teladi, uz jednak omjer spolova. Pokus je podijeljen u dva razdoblja: 1) razdoblje pokusa - starter smjesa, i 2) razdoblje pokusa - grover smjesa. U starter razdoblju telad je napajana punim pasteriziranim mlijekom i mliječnom zamjenicom i dohranjivana starter smjesom, čiji se sirovinski sastav razlikovao ovisno o udjelu u buragu nerazgradivoga škroba i bjelančevina: skupina I (36,6\% RUP i 16,5\% RUS), skupina II (49, 1\% RUP i 27,6\% RUS) i skupina III (53,5\% RUP i 36,5\% RUS). U grover razdoblju telad je hranjena mliječnom zamjenicom i grover smjesom koja se razlikovala po skupinama, ovisno o udjelu u buragu nerazgradivoga škroba i bjelančevina: skupina I (33,5\% RUP i 15,8\% RUS ), skupina II (48\% RUP i 26,3\% RUS) i skupina III (54,3\% RUP i 34,6\% RUS). Tjelesna masa i dnevni prirast u starter razdoblju bili su statistički značajno veći $(P<0,05)$ kod teladi skupine III u odnosu na telad skupine I i II $(74,75 ; 59,36 ; 66,58$ kg), kao i dnevni prirasti $(0,76,0,49,0,61 \mathrm{~kg} / \mathrm{d})$. Na kraju pokusa nije bilo značajnih razlika u tjelesnoj masi i dnevnome prirastu. Potrošnja starter smjese bila je statistički značajno veća $(P<0,05)$ kod teladi skupine I (7,48 kg/d) i III $(7,11 \mathrm{~kg} / \mathrm{d})$ u odnosu na telad skupine II $(4,33 \mathrm{~kg} / \mathrm{d})$, a statistički značajno veća $(P<0,05)$ bila je i ukupna potrošnja smjesa u istim skupinama (skupina I i II) u odnosu na telad skupine II. Vrijednosti konverzije hrane u starter razdoblju bile su, također, statistički značajno bolje $(P<0,05)$ kod teladi skupine III $(1,37 \mathrm{~kg} / \mathrm{kg})$ i II $(1,50 \mathrm{~kg} / \mathrm{kg})$ u odnosu na telad skupine I (2,08 kg/kg). Rezultati praćenja zdravstvenoga stanja teladi (proljev, pneumonija) upućuju na to da različit udio u buragu nerazgradivoga škroba i bjelančevina nisu imali izraženiji utjecaj na zdravlje teladi.

Ključne riječi: telad, hranidba, burag, nerazgradivi škrob, nerazgradive bjelančevine

(Received on 27 September 2017; accepted on 15 November 2017 - Primljeno 27. rujna 2017.; prihvaćeno 15. studenoga 2017.) 